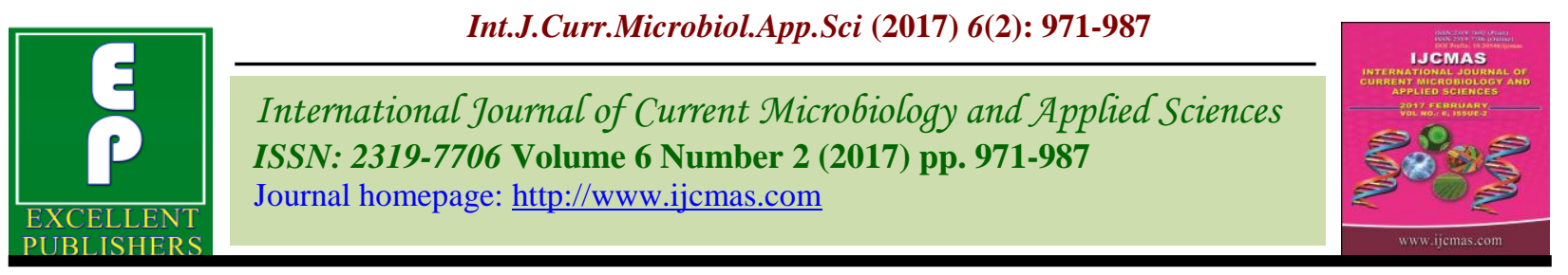

Original Research Article

http://dx.doi.org/10.20546/ijcmas.2017.602.110

\title{
Seasonal Variations in Physicochemical Characteristics of Water Samples of Surajpur Wetland, National Capital Region, India
}

\author{
Nasim Ahmad Ansari* \\ Wildlife Institute of India, Post Box No. 18 Chandrabani, Dehradun, Uttarakhand, India \\ *Corresponding author
}

\section{A B S T R A C T}

\section{Keywords}

Physicochemical parameters, Water quality analysis, Surajpur wetland, National Capital Region, India.

Article Info

Accepted:

20 January 2017

Available Online:

10 February 2017
Surajpur Lake is a prominent wetland site in National Capital Region, India, known for its rich avifaunal and aquatic biodiversity. The present study was carried out to analyse water quality and to check the relationship among various physicochemical parameters in both temporal and spatial scales from March 2012 to February 2013. The water samples were collected from five different locations on monthly basis. Standard methods were followed for the collection, sampling and analysis for 12 physicochemical parameters. The data were analyzed using PAST (version 2.15) software. One-way analysis of variance (Anova) was used to check the significance of difference among the blocks and months. Pearson linear correlation was used to check the relationship among various physicochemical parameters. The result indicates that the essential mineral nutrients are widely distributed and are within the normal range of water at various studied locations in the study area. There has no any pollution; no any organic waste is coming to the site. Nutrient levels are high in wetland habitat as wetlands have rich biomes and support high levels of biodiversity. The Anova indicates that there was no significant $(p>0.05)$ difference was found in physical parameters, chemical parameters of water quality among the different blocks and months. The proper management of Surajpur wetland provides suitable habitat for conservation of aquatic biodiversity. The conservation implications are discussed in light of results.

\section{Introduction}

Wetland ecosystem is one of the most diverse and productive ecosystems in the world and are the most vital factor for the existence of all living organisms (Ramachandran et al., 2006). The large proportion of the earth's biodiversity resides in aquatic environments (Groombridge and Jenkins, 1998). The health of wetlands and their ecological functioning are directly related to survival of aquatic organisms (Ramesh et al., 2007). To conserve these valuable resources and to prevent further deterioration, there is a need for regular monitoring of these ecosystems
(Ramachandran et al., 2006). Monitoring of water quality is the first step for the management and conservation of aquatic ecosystems. Management of an aquatic ecosystem is aimed for the conservation of its habitat by suitably maintaining the physicochemical quality of water within acceptable levels (Garg et al., 2010).

Various studies have been done to investigate the physicochemical parameters of water quality in India (Ramachandran et al., 2006; Rai et al., 2011; Azmi et al., 2015; Mishra et 
al., 2008) and very few studies have been done in northern India and National Capital Region (Mishra and Tripathi, 2007; Priyanka et al., 2016; Manral and Khudsar, 2013) and no any study have been done in the Surajpur wetland area. Hence, in the present study, an attempt has been made to study the physicochemical properties of water of Surajpur wetland to arrive at a certain conclusions on the structural and functional aspects of the reservoir and to suggest ways and means for its conservation.

\section{Materials and Methods}

\section{Study area}

Surajpur Lake $\left(28^{\circ} 31^{\prime} 425^{\prime} \mathrm{N}\right.$; $\left.77^{\circ} 29^{\prime} 714^{\prime} \mathrm{E}\right)$ is an urban wetland located in district Gautam Budh Nagar, Uttar Pradesh falls under Upper Gangetic Plains biogeographic zone, Northern India, at an elevation of 184.7 meters above mean sea level (Fig. 1). The landscape is characterized by fine alluvium and clay rich swamps, fertile soil and high water retention capacity (Manral et al., 2013). Surajpur Lake has been protected under Reserve Forest and spreads over an area of 308 hectare. The area is mainly rain-fed and other sources for water recharge are Hawaliya drain which is attached to Hindon River and Tilapta irrigation canal. The minimum and maximum air temperature ranges between $6.86^{\circ} \mathrm{C}$ and $41.69^{\circ} \mathrm{C}$, respectively and highest temperature was observed during June and the lowest during January. The season's summer, monsoon and winter represent, March to June, July to October and November to February respectively.

\section{Methods}

The study was conducted on monthly basis from March 2011 to February 2013 for the analysis of 12 physicochemical parameters. A total of five representative sampling sites were selected depending on the different stresses observed in the Surajpur wetland site, Inlet (1), Block A (2), Block B (3), Block C (4) and Outlet (5) (Fig. 1). The most changeable and sensitive water quality parameters such as Water Temperature, Water depth, pH, Transparency (Turbidity) and Dissolved Oxygen (DO) were measured insitu (Nasir, 2010; Chari, 2002), while rest parameters (Total Hardness as $\mathrm{CaCO} 3$, Total Alkalinity as $\mathrm{CaCO} 3$, Chloride, Nitrate, Fluoride, Phosphate and Total Iron) were analysed in the laboratory. For collection of water samples, wide mouth sterile transparent plastic jars of half liter capacity used and 10$20 \mathrm{~cm}$ depth of water surface were considered for collection during $0800-1000 \mathrm{hr}$., brought to the laboratory and preserved under refrigerated condition for analysis (Mishra et al., 2008). Preservation of samples and estimation of various water quality parameters were done as per standard procedures reported in APHA, (2006) and Golterman et al., (1978). The apparatus used for transparency measurement was Secchi disc having a diameter of $20 \mathrm{~cm}$ and painted with black and white quadrants (Golterman et al., 1978). The results of the physicochemical analysis of the water samples compared with the Indian Standards Institute (IS, 105001989), Bureau of Indian Standards (BIS, 1993) and Central Pollution Control Board (CPCB) (Table 1).

Data analysis was performed by using PAST software (Versions 3.08) (Hammer et al., 2001). One-way analysis of variance (ANOVA) was used for hydrological and meteorological parameters to calculate any existence of difference among the blocks and months. In the event of significance $(\mathrm{P}>0.05)$, a post hoc Tukey HSD test was used to determine which means were significantly different at a 0.05 level of probability (Spjotvoll and Stoline, 1973). Pearson linear correlation was played to check the relationship between various physicochemical parameters. 
Figure.1 Map of the study area showing five water quality monitoring locations

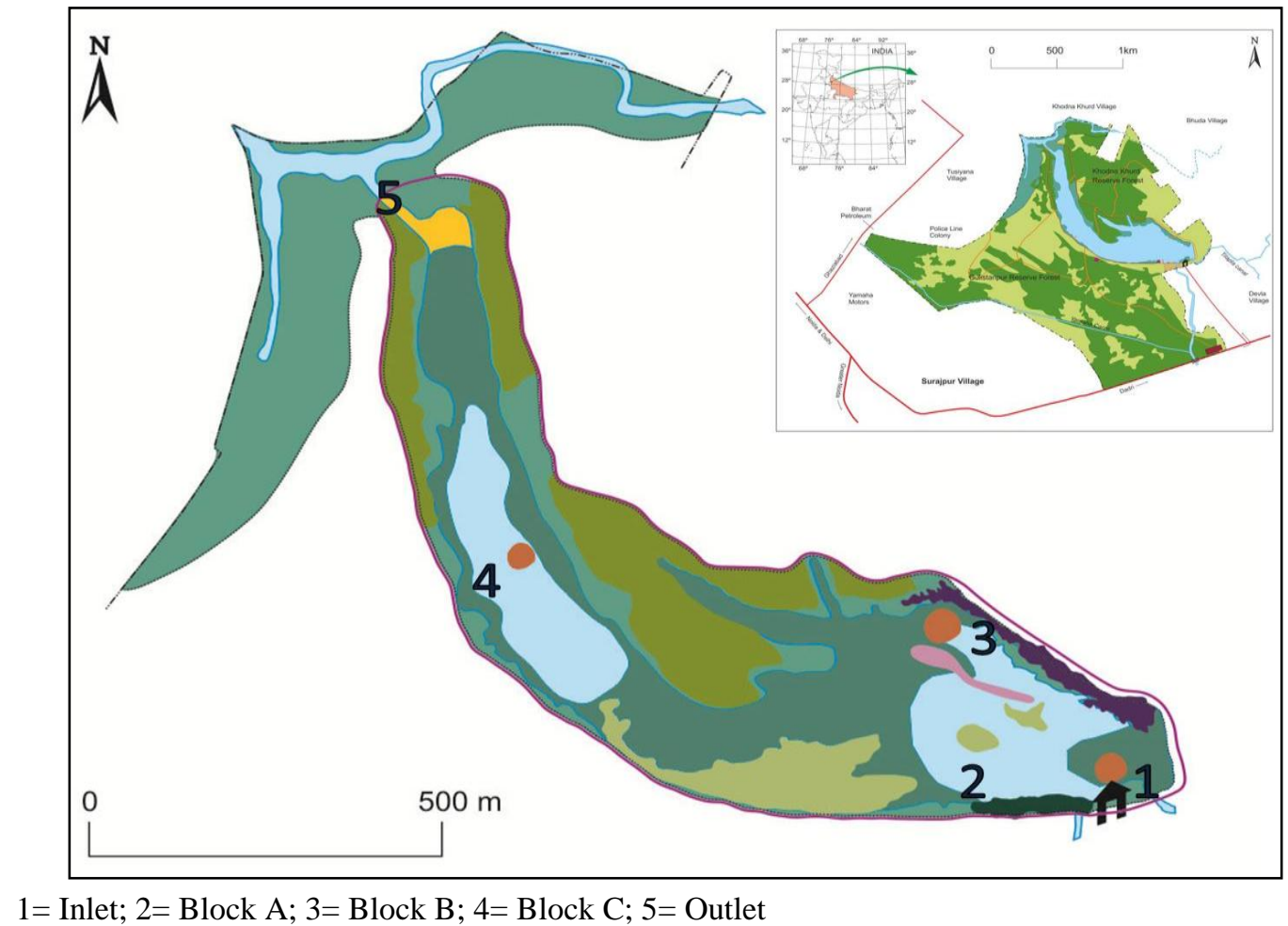

\section{Results and Discussion}

The results of various physiochemical parameters of water samples are given in table 2. During the study period, the $\mathrm{pH}$ value in water has remained more or less uniform throughout the study period and did not fluctuate by more than one unit and the value ranges between $6.03 \pm 0.04$ (Monsoon 201213 ) to $6.55 \pm 0.15$ (Summer and Winter 201112). This indicates that the water was faintly acidic in nature and the value was slightly lower side of the permissible limits (6.5-8.5). On seasonal basis, the $\mathrm{pH}$ value recorded vaguely higher in 2011-12 (6.50) as compared to 2012-13 (6.15) (Fig. 2). The water temperature ranges between $15.43 \pm 5.79^{\circ} \mathrm{C}$ (Winter 2012-13) and $28.60 \pm 3.70^{\circ} \mathrm{C}$ (Summer 2011-12) and the average temperature recorded slightly lower in 2012 $13\left(23.42^{\circ} \mathrm{C}\right)$ as compared to $2011-12$ $\left(24.50^{\circ} \mathrm{C}\right)$ (Table 2; Fig. 3).
Water depth was recorded for all 5 stations of the study area. During the study period, water depth level ranged between $43.00 \pm 11.00 \mathrm{~cm}$ (Summer 2011-12) and $90.00 \pm 19.00 \mathrm{~cm}$ (Monsoon 2011-12) (Table 2) and the average temperature recorded similar in both the study years 2011-12 and 2012-13 (Fig. 4). The water depth level recorded higher in monsoon in both the years $(90.00 \pm 19.00 \mathrm{~cm}$ in $2011-12$ and $88.00 \pm 14.00 \mathrm{~cm}$ in $2012-13$ ), because most of the rainfall received during monsoon season in the area. The seasonal mean values of turbidity varied from a minimum $22.95 \pm 6.15 \mathrm{~cm}$ in summer 2011-12 to maximum $46.60 \pm 1.35 \mathrm{~cm}$ in monsoon 201112 . The average turbidity value recorded more or less similar in both the years of the study that is $32.58 \mathrm{~cm}$ in $2011-12$ and $32.93 \mathrm{~cm}$ in 2012-13 (Table 2) and value lies under the permissible limits (Table 1). 
In the present study, dissolved oxygen (DO) revealed a definite seasonal trend consisting high values in winter 2011-12 $(15.30 \pm 2.02 \mathrm{mg} / \mathrm{l})$ and low in monsoon 2011 $12(06.79 \pm 03.50 \mathrm{mg} / \mathrm{l})$ (Table 2; Fig. 5). The average dissolved oxygen in both the study years was not much fluctuated and the values recorded slightly higher in 2011-12 $(11.10 \mathrm{mg} / \mathrm{l})$ than in $2012-13(10.81 \mathrm{mg} / \mathrm{l})$ and these values are higher than the permissible limits. The Anova indicated that there was no significant $(\mathrm{P}<0.05)$ difference was found in physical parameters of water quality among the different blocks and months. The Total hardness as Calcium carbonate value ranges between $288.00 \pm 19.33 \mathrm{mg} / \mathrm{l}$ (winter 2012-13) and $158.40 \pm 39.22 \mathrm{mg} / \mathrm{l}$ (monsoon 2012-13) (Table 2 and Fig. 6). The year wise overall average hardness recorded lower in 2011-12 $(229.93 \mathrm{mg} / \mathrm{l})$ and higher in 2012-13 $(231.45 \mathrm{mg} / \mathrm{l})$ and these values lie under the permissible limits (Table 1).

Total Alkalinity as Calcium carbonate concentration in water recorded a gradual decreasing trend from summer $(303.60 \pm 59.60 \mathrm{mg} / \mathrm{l})$ followed by monsoon $(272.50 \pm 37.50 \mathrm{mg} / \mathrm{l})$ and winter $(222.00 \pm 137.00 \mathrm{mg} / \mathrm{l})$ in $2011-12$ whereas in 2012-13, winter recorded maximum $(340.00 \pm 74.24 \mathrm{mg} / \mathrm{l})$ and monsoon recorded minimum $(203.00 \pm 39.74 \mathrm{mg} / \mathrm{l})$ values. The overall average alkalinity values recorded slightly lower $(266.03 \mathrm{mg} / \mathrm{l})$ in $2011-12$ than in 2012-13 (281.83mg/l) (Table 2; Fig. 7).

The chloride concentration of the water samples ranged from $39.90 \mathrm{mg} / \mathrm{l}$ (monsoon 2012-13) to $103.30 \mathrm{mg} / \mathrm{l}$ (summer 2011-12) (Table 2). The average annual chloride level in water recorded not much fluctuating (74.30mg/l in $2011-12$ and $76.94 \mathrm{mg} / 1$ in 2012-13) and the values lie under the permissible limits (Table 1) except the values of monsoon 2011-12, which is slightly lower than the tolerance limit. The temporal variation of chloride is given in figure 8 .
The overall Nitrate concentration in water body ranged between $1.90 \pm 0.90 \mathrm{mg} / \mathrm{l}$ (monsoon 2011-12) and 12.67 $\pm 8.38 \mathrm{mg} / \mathrm{l}$ (summer 2012-13). On temporal basis, Nitrate recorded maximum in winter $(7.70 \pm 2.85 \mathrm{mg} / \mathrm{l})$ and minimum in monsoon $(1.90 \pm 0.90 \mathrm{mg} / \mathrm{l})$ in 2011-12 whereas in 2012-13 it shows a gradual decrease from summer $(12.67 \pm 8.38 \mathrm{mg} / \mathrm{l})$ followed by monsoon $(5.32 \pm 4.97 \mathrm{mg} / \mathrm{l})$ and winter $(3.70 \pm 2.98 \mathrm{mg} / \mathrm{l})$ (Table 2; Fig. 9). The annual average alkalinity values recorded slightly lower $(4.13 \mathrm{mg} / \mathrm{l})$ in 2011-12 than in 2012-13 $(7.23 \mathrm{mg} / \mathrm{l})$ and the values fall under the permissible limits (Table 1).

Fluoride concentration in water body recorded presence of only $1 \mathrm{mg} / \mathrm{l}$ in all the samples (Table 2) throughout the study period and the values lie under the permissible limits (Table 1). The overall Phosphate concentration in water body ranged between $0.52 \pm 0.08 \mathrm{mg} / \mathrm{l}$ (summer 2011-12) and $0.84 \pm 0.20 \mathrm{mg} / \mathrm{l}$ (summer 2012-13). On temporal basis, Phosphate recorded maximum in monsoon $(0.71 \pm 0.07 \mathrm{mg} / \mathrm{l})$ and minimum in summer $(0.52 \pm 0.08 \mathrm{mg} / \mathrm{l})$ in $2011-12$ whereas in 2012 13 it shows a gradual decrease from summer $(0.84 \pm 0.20 \mathrm{mg} / \mathrm{l})$ followed by monsoon $(0.65 \pm 0.10 \mathrm{mg} / \mathrm{l})$ and winter $(0.64 \pm 0.10 \mathrm{mg} / \mathrm{l})$ (Table 2; Fig. 10). The annual average alkalinity values recorded slightly lower $(0.60 \mathrm{mg} / \mathrm{l})$ in $2011-12$ than in 2012-13 $(0.71 \mathrm{mg} / \mathrm{l})$, though the values fall under the permissible limits (Table 1).

The total Iron concentration of the water samples ranged from $1.37 \pm 0.17 \mathrm{mg} / \mathrm{l}$ (monsoon 2011-12) to $3.0 \pm 0.0 \mathrm{mg} / \mathrm{l}$ (winter 2011-12) (Table 2). The temporal variation of Iron is given in figure 11. The average annual Chloride level in water recorded not much fluctuating $(1.98 \mathrm{mg} / \mathrm{l}$ in $2011-12$ and $1.60 \mathrm{mg} / \mathrm{l}$ in 2012-13) and the values lies under the permissible limits (Table 1). The Anova indicated that there was no significant $(\mathrm{P}<0.05)$ difference was found in chemical 
parameters of water quality among the different blocks and months. The Pearson linear correlation implies that water temperature has significant negative correlation with DO ( $\mathrm{r}=-0.59)$, hardness ( $\mathrm{r}-$ $0.68)$, Nitrate $(\mathrm{r}=-0.49)$ and Iron $(\mathrm{r}=-0.69)$; water depth has significant positive correlation with water temperature $(r=0.54)$ and turbidity $(\mathrm{r}=0.83)$, whereas negative correlation with DO $(\mathrm{r}=-0.57)$, hardness $(\mathrm{r}=-$ 0.63) and Chloride ( $\mathrm{r}=-0.62) ; \mathrm{pH}$ showed significant positive correlation with water temperature $(\mathrm{r}=0.84)$ and water depth $(\mathrm{r}=0.98)$; Turbidity showed significant positive correlation with $\mathrm{pH}$ and Phosphate and negative correlation with DO, hardness and Chloride; DO showed significant positive correlation with $\mathrm{pH}$, hardness and Chloride, whereas significant negative correlation with Phosphate (Table 3). Among chemical parameters, hardness showed significant positive correlation with $\mathrm{pH}$, Chloride, Nitrate; whereas alkalinity showed significant positive correlation with water depth, $\mathrm{pH}$, turbidity, DO and hardness. Chloride showed significant positive correlation with water temperature, $\mathrm{pH}$ and significant negative correlation with Phosphate. Nitrate showed significant positive correlation with $\mathrm{pH}$, turbidity, alkalinity, Chloride whereas Phosphate significant positive correlation with water temperature, $\mathrm{pH}$, alkalinity, Nitrate. Iron content showed significant positive correlation with water depth, $\mathrm{pH}$, turbidity, hardness, chloride and phosphate (Table 3). Hence, positive correlation suggests that, with the increase of one parameter, other parameters were also increased whereas an inverse relationship suggests that, with the decrease of one parameter, other parameters increased.

Table.1 Permissible limits of physicochemical parameters of water samples

\begin{tabular}{|c|l|l|}
\hline S. No. & Physicochemical parameters & Permissible limits* \\
\hline 1. & pH & $\mathbf{6 . 5 - 8 . 5}$ \\
\hline 2. & Water Temperature $\left({ }^{\circ} \mathrm{C}\right)$ & $<\mathbf{4 0}$ \\
\hline 3. & Turbidity $($ Transparency) & $<\mathbf{1 0 0} \mathbf{~ m g} / \mathbf{l}$ \\
\hline 4. & DO $(\mathrm{mg} / \mathrm{l})$ & $\mathbf{3 . 0 - 6 . 0}$ \\
\hline 5. & Total Hardness as CaCO3 $(\mathrm{mg} / \mathrm{l})$ & $\mathbf{3 0 0}$ \\
\hline 6. & Total Alkalinity as $\mathrm{CaCO} 3(\mathrm{mg} / \mathrm{l})$ & $\mathbf{2 0 0}$ \\
\hline 7. & Chloride $(\mathrm{mg} / \mathrm{l})$ & $\mathbf{7 5 - 2 0 0}$ \\
\hline 8. & Nitrate $(\mathrm{mg} / \mathrm{l})$ & $<\mathbf{4 5 . 0}$ \\
\hline 9. & Fluoride $(\mathrm{mg} / \mathrm{l})$ & $\mathbf{1}$ \\
\hline 10. & Phosphate $(\mathrm{mg} / \mathrm{l})$ & $\mathbf{5}$ \\
\hline 11. & Total Iron $(\mathrm{mg} / \mathrm{l})$ & $\mathbf{0 . 1 - 3 . 0}$ \\
\hline
\end{tabular}

*As per Indian Standards Institution (IS 10500-1989), Bureau of Indian Standard (BIS), Union Health Ministry and Central Pollution Control Board (CPCB) 
Table.2 Results of water quality analysis of various physicochemical parameters

\begin{tabular}{|l|l|l|l|l|l|l|l|l|}
\hline \multirow{2}{*}{ Physicochemical parameters } & \multicolumn{2}{|l|}{$\mathbf{2 0 1 1 - 2 0 1 2}$} & $\mathbf{2 0 1 2 - 1 3}$ \\
\cline { 2 - 9 } & Summer & Monsoon & Winter & Mean & Summer & Monsoon & Winter & Mean \\
\hline pH & 6.55 & 6.40 & 6.55 & $\mathbf{6 . 5 0}$ & 6.28 & 6.03 & 6.15 & $\mathbf{6 . 1 5}$ \\
\hline Water Temperature $\left({ }^{\circ} \mathrm{C}\right)$ & 28.60 & 27.80 & 17.10 & $\mathbf{2 4 . 5 0}$ & 27.68 & 27.17 & 15.43 & $\mathbf{2 3 . 4 2}$ \\
\hline Water Depth $(\mathrm{cm})$ & 43.00 & 90.00 & 62.00 & $\mathbf{6 5 . 0 0}$ & 46.00 & 88.00 & 61.00 & $\mathbf{6 5 . 0 0}$ \\
\hline Turbidity $(\mathrm{cm})$ & 22.95 & 46.60 & 28.20 & $\mathbf{3 2 . 5 8}$ & 27.18 & 43.30 & 28.33 & $\mathbf{3 2 . 9 3}$ \\
\hline Dissolved Oxygen $(\mathrm{DO})(\mathrm{mg} / \mathrm{l})$ & 11.22 & 6.79 & 15.30 & $\mathbf{1 1 . 1 0}$ & 11.49 & 8.45 & 12.49 & $\mathbf{1 0 . 8 1}$ \\
\hline Total Hardmess as CaCO3 $(\mathrm{mg} / \mathrm{l})$ & 230.00 & 183.80 & 276.00 & $\mathbf{2 2 9 . 9 3}$ & 247.95 & 158.40 & 288.00 & $\mathbf{2 3 1 . 4 5}$ \\
\hline Total Alkalinity as CaCO3 $(\mathrm{mg} / \mathrm{l})$ & 303.60 & 272.50 & 222.00 & $\mathbf{2 6 6 . 0 3}$ & 302.50 & 203.00 & 340.00 & $\mathbf{2 8 1 . 8 3}$ \\
\hline Chloride $(\mathrm{mg} / \mathrm{l})$ & 103.30 & 43.10 & 76.50 & $\mathbf{7 4 . 3 0}$ & 100.13 & 39.90 & 90.80 & $\mathbf{7 6 . 9 4}$ \\
\hline Nitrate $(\mathrm{mg} / \mathrm{l})$ & 2.80 & 1.90 & 7.70 & $\mathbf{4 . 1 3}$ & 12.67 & 5.32 & 3.70 & $\mathbf{7 . 2 3}$ \\
\hline Fluoride $(\mathrm{mg} / \mathrm{l})$ & 1.00 & 1.00 & 1.00 & $\mathbf{1 . 0 0}$ & 1.00 & 1.00 & 1.00 & $\mathbf{1 . 0 0}$ \\
\hline Phosphate $(\mathrm{mg} / \mathrm{l})$ & 0.52 & 0.71 & 0.57 & $\mathbf{0 . 6 0}$ & 0.84 & 0.65 & 0.64 & $\mathbf{0 . 7 1}$ \\
\hline Total Iron $(\mathrm{mg} / \mathrm{l})$ & 1.56 & 1.37 & 3.00 & $\mathbf{1 . 9 8}$ & 1.40 & 1.58 & 1.83 & $\mathbf{1 . 6 0}$ \\
\hline
\end{tabular}


Table.3 Correlation matrix among various physicochemical parameters

\begin{tabular}{|c|c|c|c|c|c|c|c|c|c|c|c|}
\hline & $\begin{array}{l}\text { Water } \\
\text { Temp. } \\
\left({ }^{\circ} \mathrm{C}\right)\end{array}$ & Water depth & $\mathbf{p H}$ & Turbidity & $\begin{array}{l}\text { DO } \\
(\mathrm{mg} / \mathrm{l})\end{array}$ & $\begin{array}{l}\text { Total } \\
\text { Hardne } \\
\text { ss as } \\
\text { CaCO3 }\end{array}$ & $\begin{array}{l}\text { Total } \\
\text { Alkalinity } \\
\text { as CaCO3 }\end{array}$ & Chloride & Nitrate & Phosphate & $\begin{array}{l}\text { Total } \\
\text { Iron }\end{array}$ \\
\hline Water Temp. $\left({ }^{\circ} \mathrm{C}\right)$ & 0.00 & $0.54 *$ & $\begin{array}{c}0.84 \\
*\end{array}$ & 0.44 & 0.04 & 0.01 & 0.48 & $0.55^{*}$ & 0.04 & $0.90 *$ & 0.01 \\
\hline Water depth & 0.20 & 0.00 & $\begin{array}{c}0.98 \\
*\end{array}$ & 0.00 & 0.05 & 0.03 & $0.84 *$ & 0.03 & 0.40 & 0.17 & $0.97 *$ \\
\hline $\mathbf{p H}$ & 0.06 & 0.01 & 0.00 & $0.71 *$ & $0.50 *$ & $0.77 *$ & $0.68 *$ & $0.80 *$ & $0.92 *$ & $0.90 *$ & $0.76^{*}$ \\
\hline Turbidity & 0.25 & $0.83 *$ & -0.12 & 0.00 & 0.03 & 0.04 & $0.52 *$ & 0.00 & $0.59 *$ & 0.07 & $0.64 *$ \\
\hline DO (mg/l) & $-0.59 *$ & $-0.57 *$ & 0.22 & $-0.64 *$ & 0.00 & 0.00 & $0.95^{*}$ & 0.01 & 0.25 & 0.01 & 0.36 \\
\hline $\begin{array}{c}\text { Total Hardness as } \\
\text { CaCO3 }\end{array}$ & $-0.68 *$ & $-0.63 *$ & 0.09 & $-0.60 *$ & $0.83 *$ & 0.00 & $0.74 *$ & 0.02 & 0.05 & 0.20 & $0.75^{*}$ \\
\hline $\begin{array}{c}\text { Total Alkalinity as } \\
\text { CaCO3 }\end{array}$ & 0.22 & -0.07 & 0.13 & -0.21 & 0.02 & 0.11 & 0.00 & 0.47 & $0.57 *$ & $0.83 *$ & 0.42 \\
\hline Chloride & -0.19 & $-0.62 *$ & -0.08 & $-0.81 *$ & $0.72 *$ & $0.68 *$ & 0.23 & 0.00 & $0.62 *$ & 0.00 & $0.77 *$ \\
\hline Nitrate & $-0.59 *$ & -0.27 & 0.03 & -0.17 & 0.36 & $0.57 *$ & -0.18 & 0.16 & 0.00 & $0.50 *$ & 0.31 \\
\hline Phosphate & 0.04 & 0.42 & -0.04 & $0.55^{*}$ & $0.71 *$ & -0.40 & -0.07 & $-0.77 *$ & 0.21 & 0.00 & $0.74 *$ \\
\hline Total Iron & $-0.69 *$ & 0.01 & -0.10 & -0.15 & 0.29 & 0.11 & -0.26 & -0.10 & 0.32 & 0.11 & 0.00 \\
\hline
\end{tabular}


Figure.2 Seasonal variations in $\mathrm{pH}$ values during the study period in Surajpur wetland

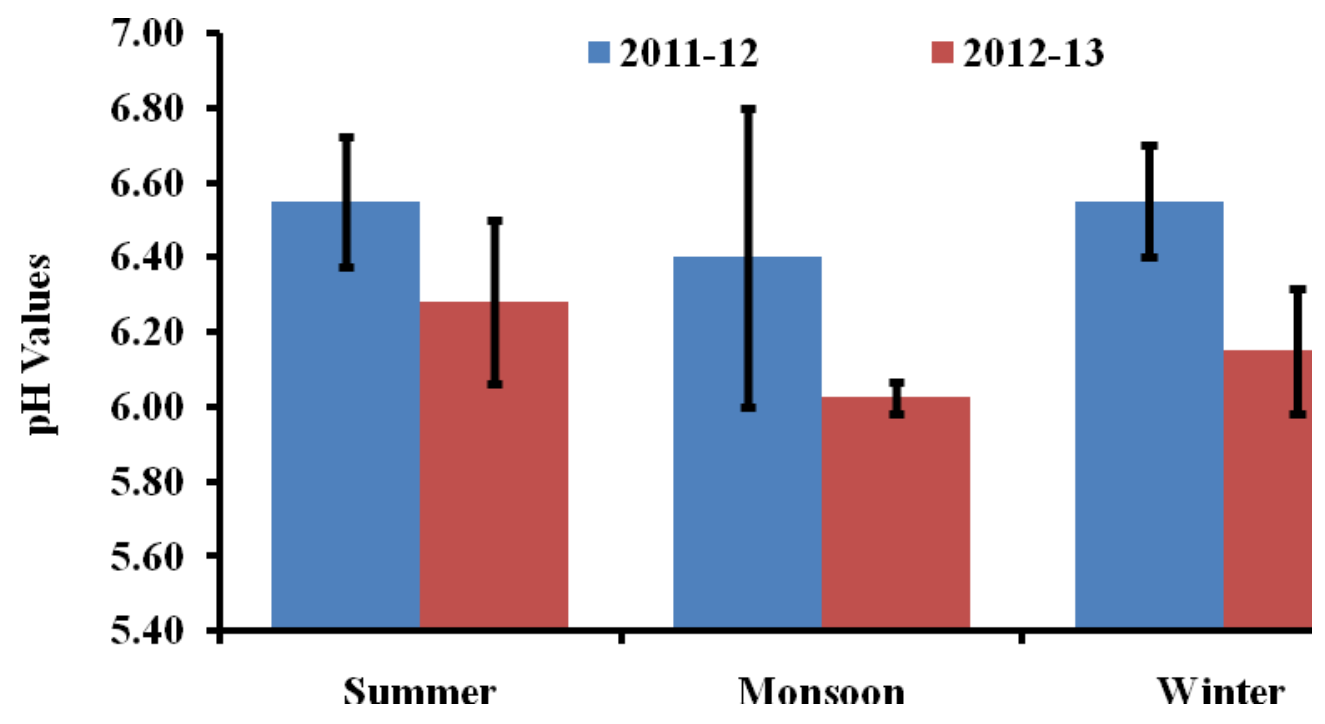

Figure.3 Seasonal variations in Water Temperature during the study period

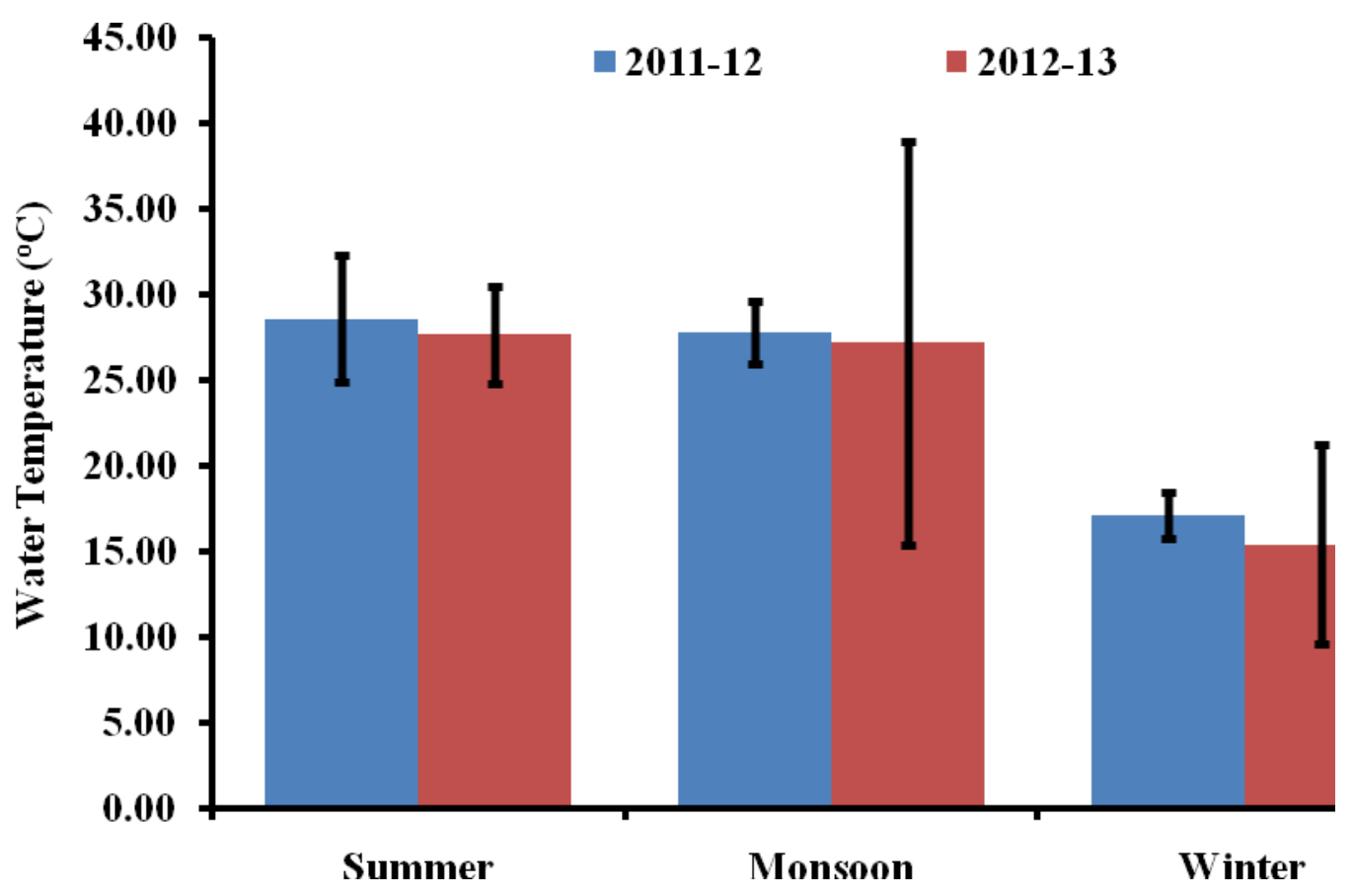


Figure.4 Seasonal variations in Water Depth during the study period

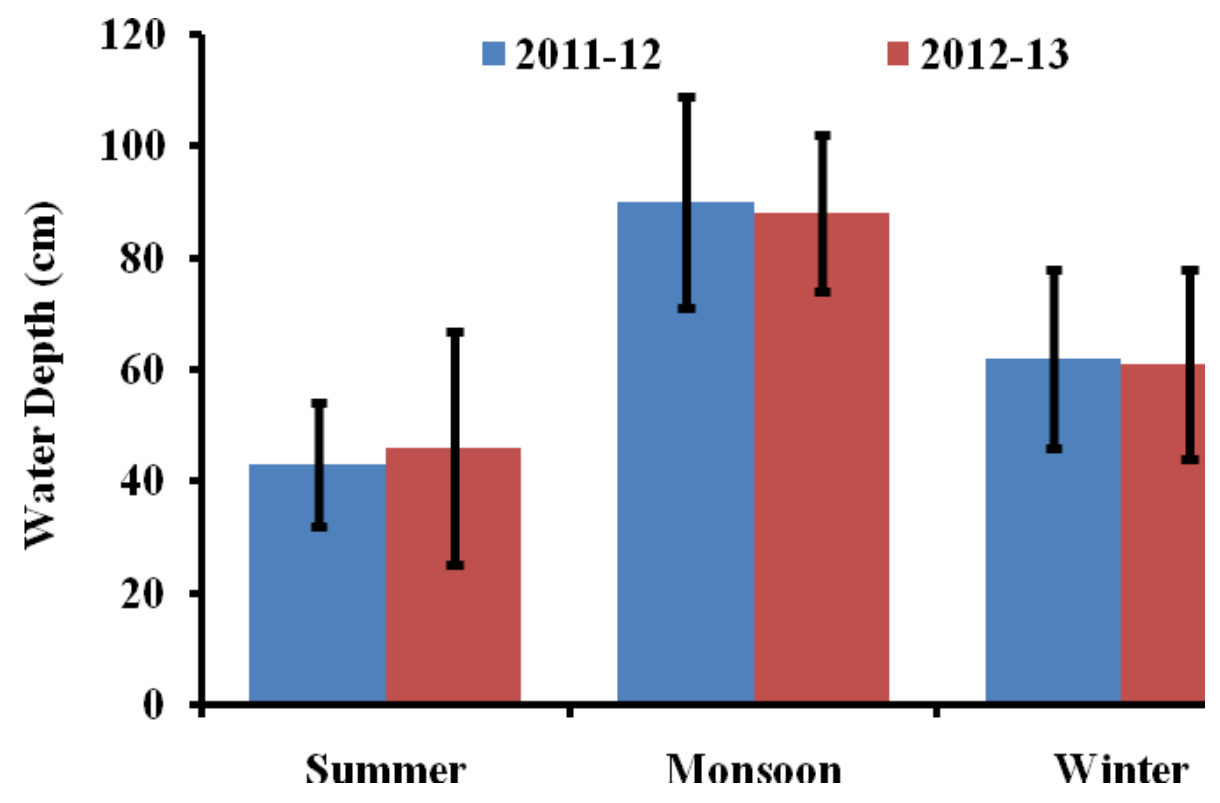

Figure.5 Seasonal variations in Dissolved Oxygen (DO) during the study period

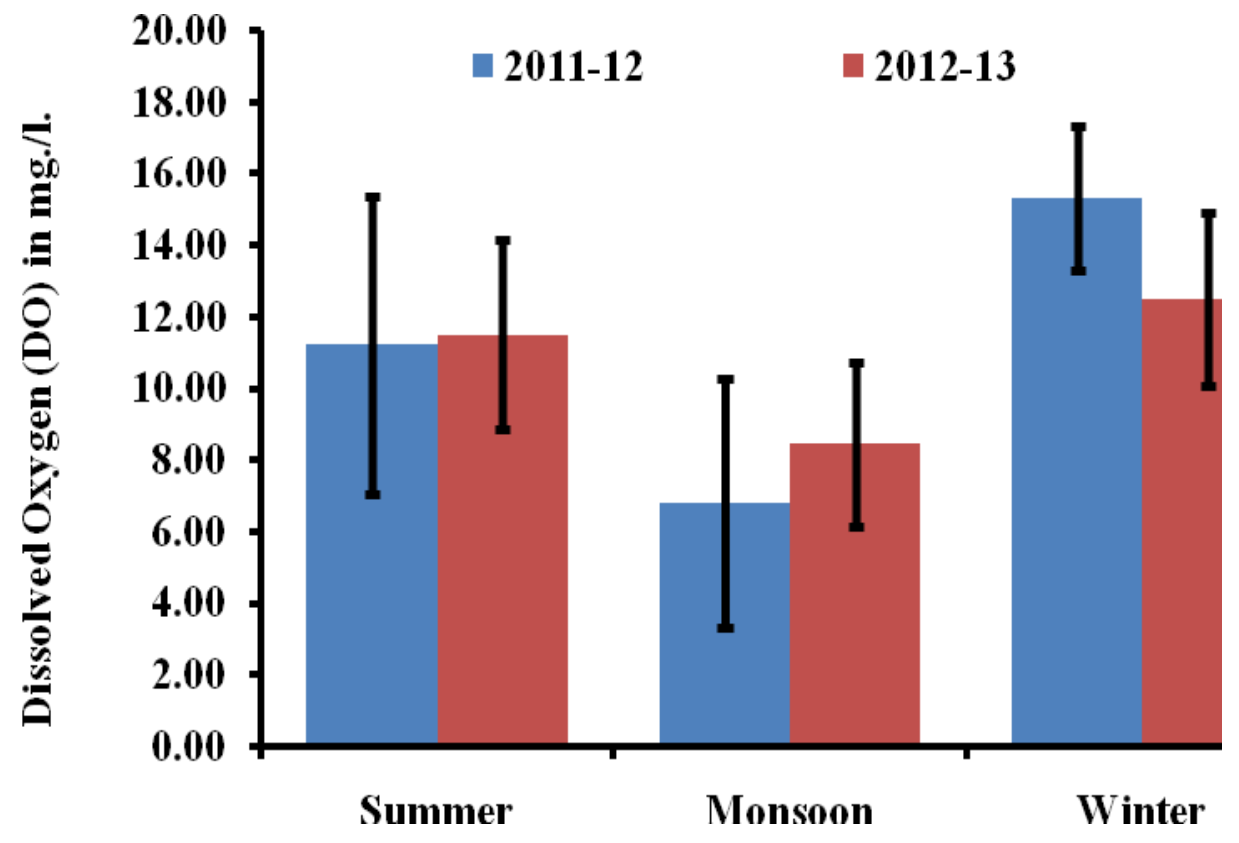


Figure.6 Seasonal variations in Total Hardness as $\mathrm{CaCO} 3$ during the study period

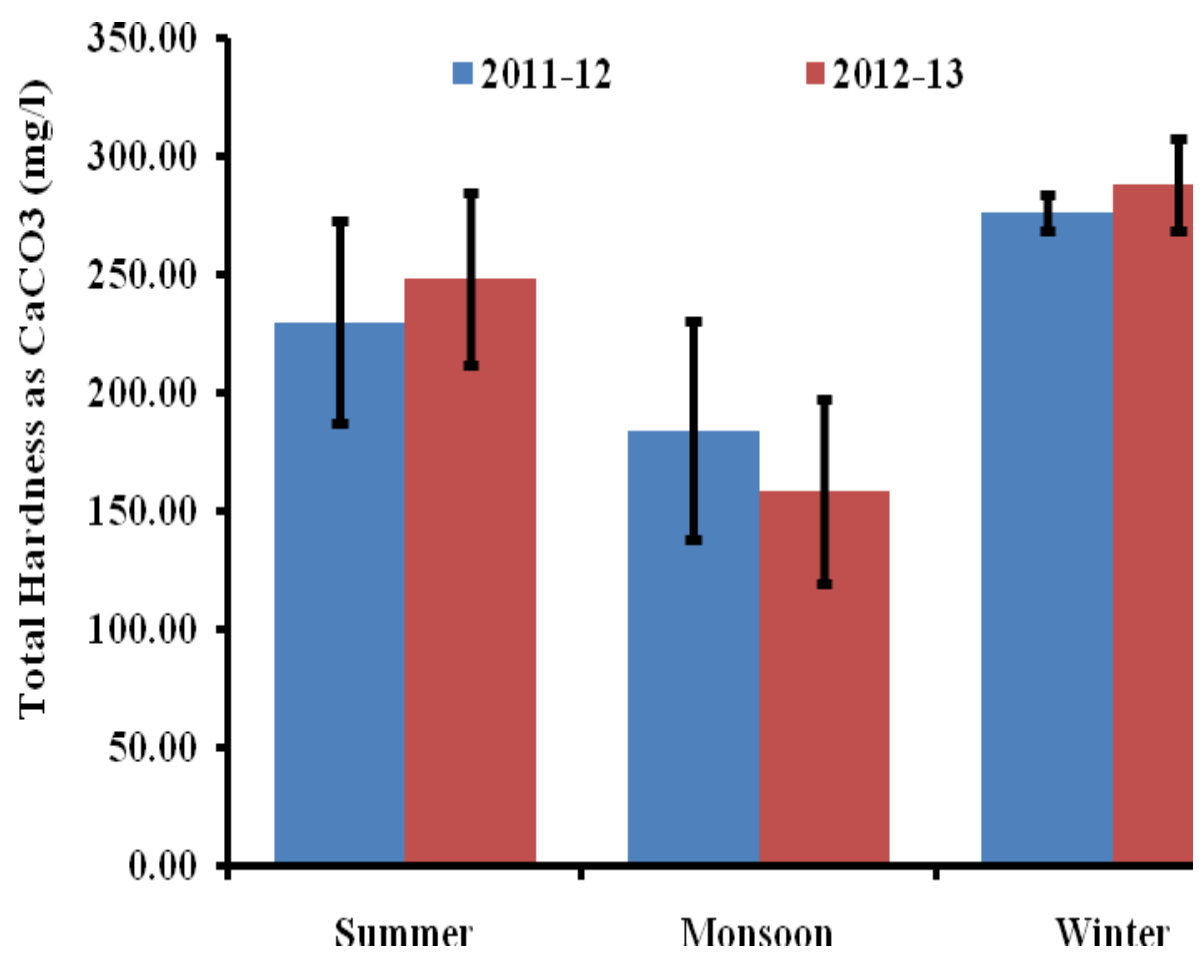

Figure.7 Seasonal variations in Total Alkalinity as $\mathrm{CaCO} 3$ during the study period

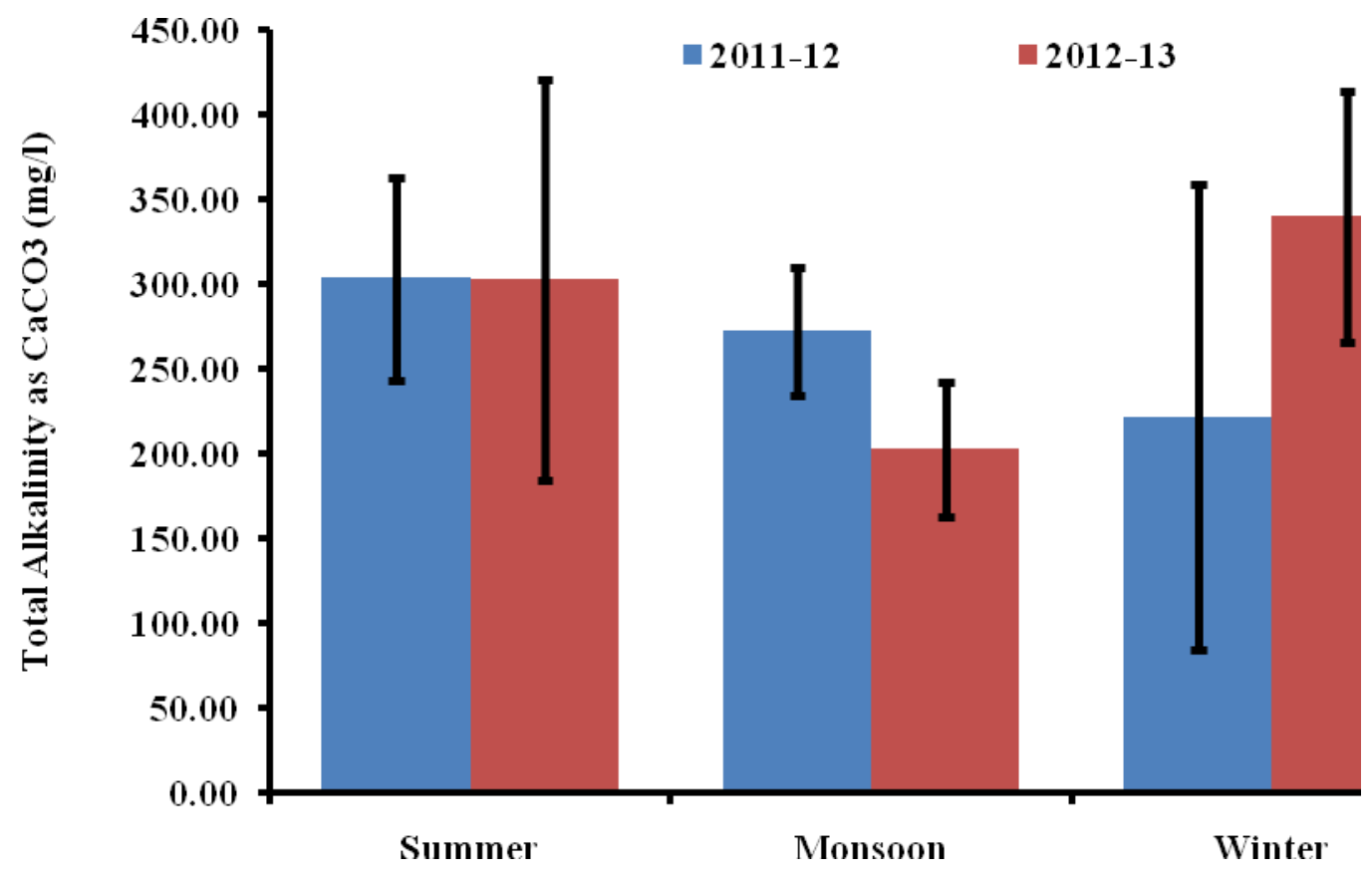


Figure.8 Seasonal variations in Chloride during the study period

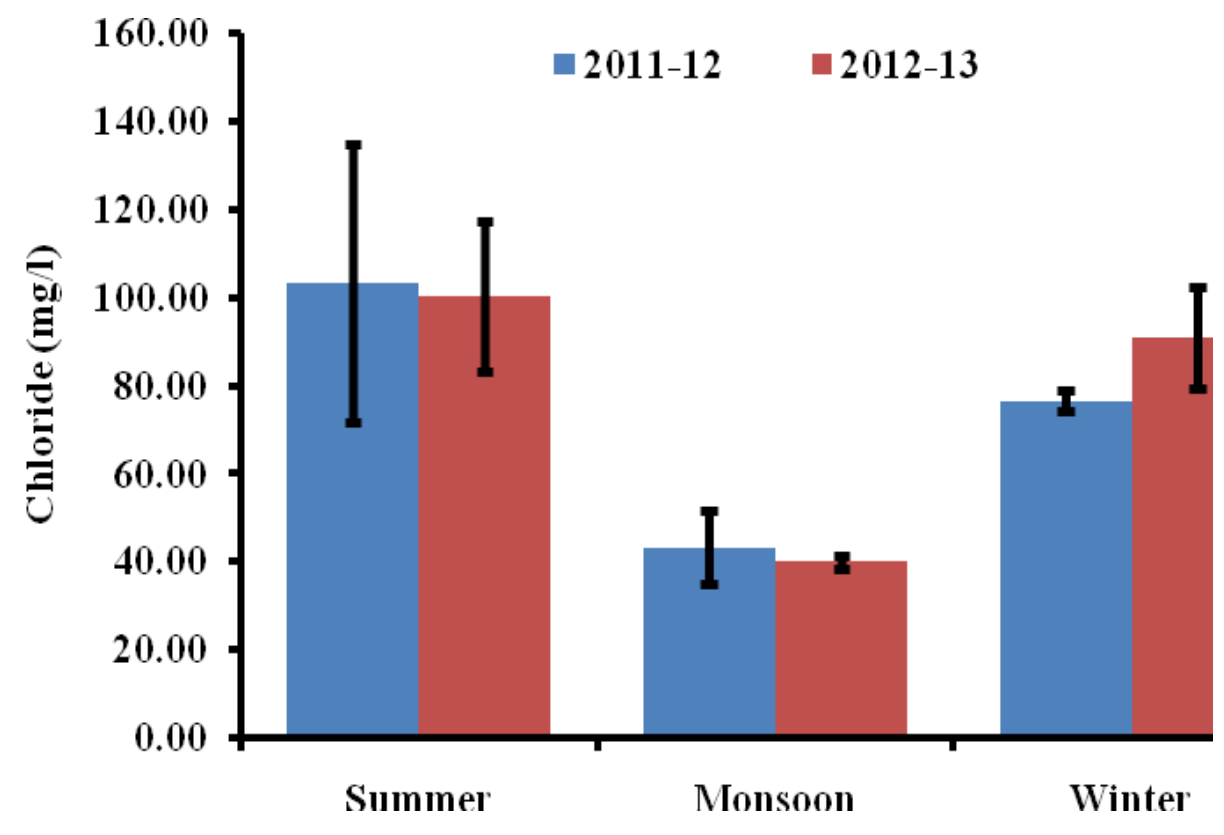

Figure.9 Seasonal variations in Nitrate during the study period in Surajpur wetland

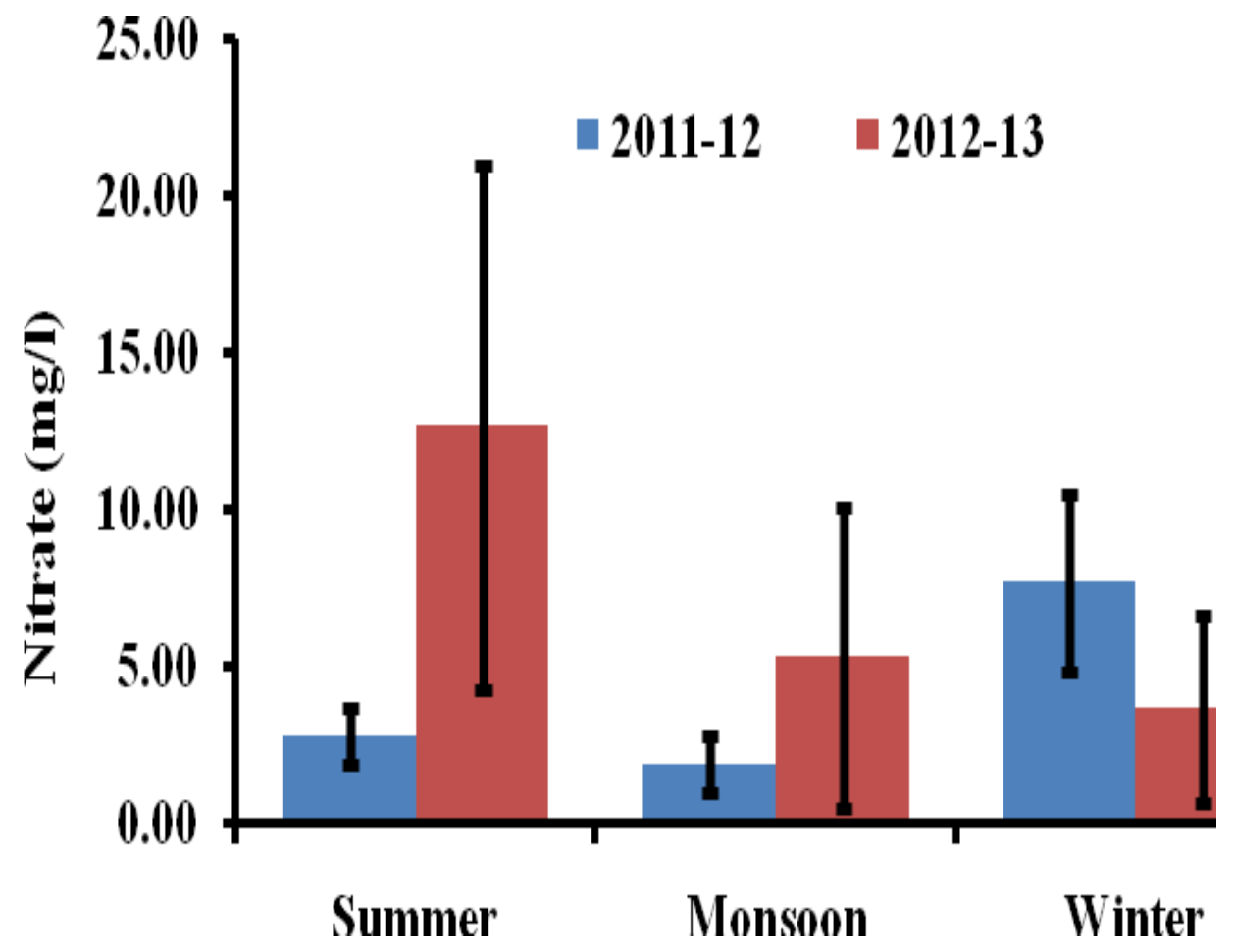


Figure.10 Seasonal variations in Phosphate during the study period in Surajpur wetland

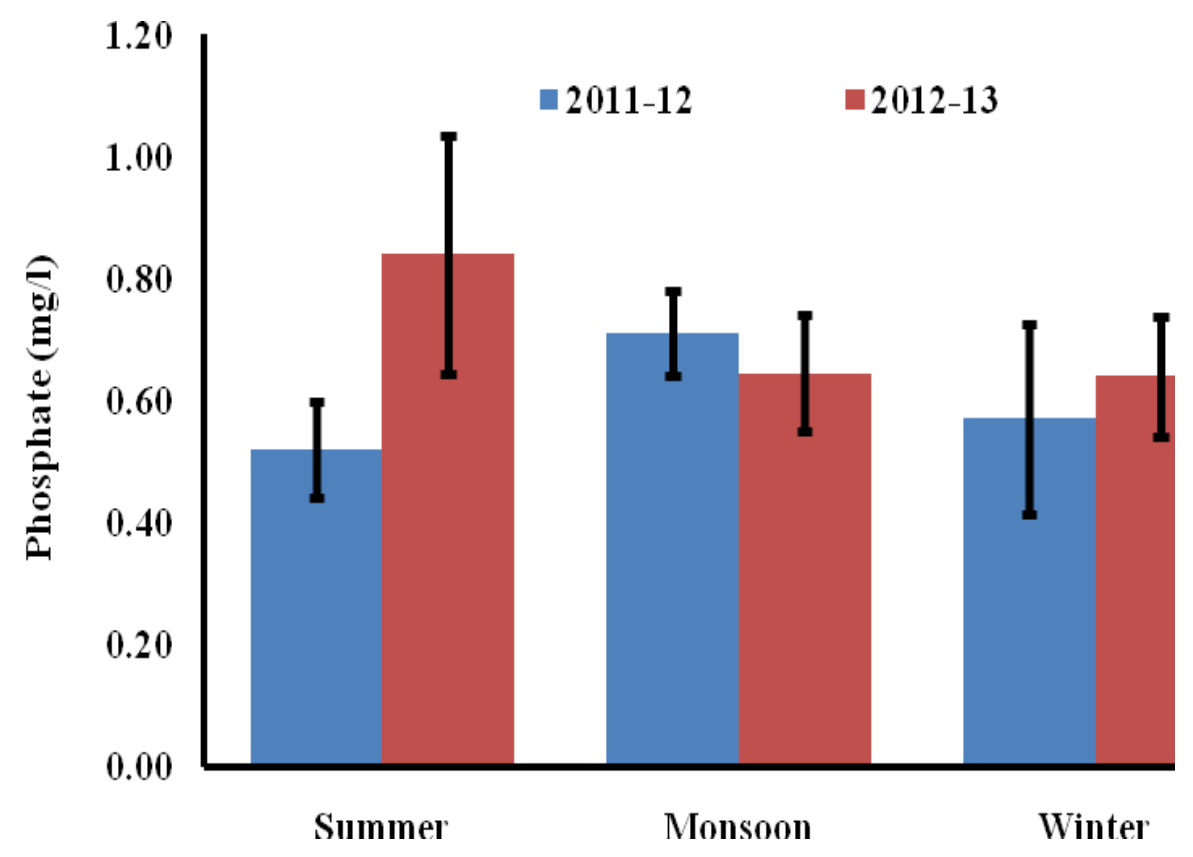

Figure.11 Seasonal variations in Iron during the study period in Surajpur wetland

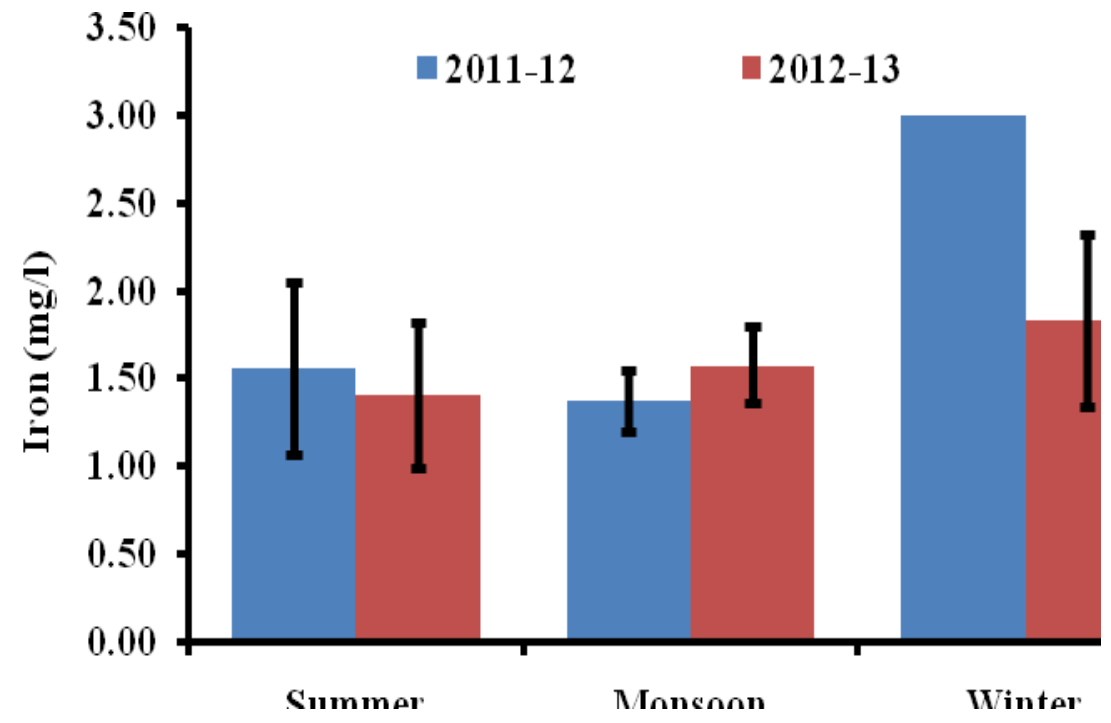

The data generated for water quality represents both spatial and temporal variance in the lake. The $\mathrm{pH}$ is an important parameter which determines the suitability of water for various purposes (Shah, 2012). In the present investigation, $\mathrm{pH}$ indicates that the water was faintly acidic in nature and the value was slightly lower side of the permissible limits (6.5-8.5). Sahu et al., (1995) and Ramadas et $a l$. , (2005) also reported variations in $\mathrm{pH}$ level 
due to inflow of waste as also seasonal changes. Eshleman and Hemond, 1985; Kerekes et al., 1986 also shows acidic pH in all the seasons, due to the contribution of total organic carbon through organic acids, which may come from excessive growth of an aquatic weed Water Hyacinth Eichhornea crassipes in the wetland area. Although these small changes in $\mathrm{pH}$ are not likely to have a direct impact on aquatic life, they greatly influence the availability and solubility of all chemical forms in the lake and may aggravate nutrient problems.

Spatially, water temperature represents no significant difference among various stations throughout the study period, whereas temporally, lower water temperature was observed from December to February and higher temperature was recorded from March to June. Das et al., (2000, 2001 a, b) and Das and Saksena, (2001) have described water temperature fluctuation due to seasonal changes in ambient temperature. The thermal behaviour of a water body in a tropical belt is primarily influenced by atmospheric conditions (Rajashree, 1996).

The depth of water is one of the major physical factors which act as a controlling factor for determining the water quality as well as the wealth of flora and fauna (Shah, 2012). Spatially, there was no significant difference in the water depth levels among various stations throughout the study period, whereas seasonally, lower water depth level was observed from March to June and higher water depth was from July to October. The deviation in water depth level recorded higher in summer 2012-13 because of fluctuations in availability of water by the Forest Department and release of water in Tilapta Canal by Irrigation Department.

Turbidity (transparency) is an optical property of the water body; it is due to suspended matter in water and it was fluctuated temporally across the study period. In general, the high turbidity values were recorded in monsoon season and low in summer season due to highest suspended matter in water in monsoon season as it receives maximum rainfall. The deviation in turbidity values recorded higher in 2012-13 because of fluctuations in water availability and number of rainy days.

Dissolve oxygen (DO) is a very important indicator of a water body's ability to support aquatic life. In the present study, higher deviations recorded in 2011-12 because of management activities like removal of water hyacinth Eichhornea crassipes ongoing in the wetland area. The high DO values in winter 2011-12 suggesting that more oxygen production due to massive spread and extensive growth of aquatic vegetation in sluggish water body, whereas in monsoon due to heavy rainfall, the area becomes flooded and little spread of aquatic vegetation resulting low DO values. As cold water contains more oxygen than warm water, therefore temperature increases, dissolved oxygen decreases in summer and monsoon and increases in winter. During dry seasons, water levels decrease and the flow rate of a river slows down. As the water moves slower, it mixes less with the air, and the DO concentration decreases. Organisms living in the water breathe the oxygen dissolved in the water (Nasir, 2010). Dissolved oxygen (DO) is essential to aquatic life and plays an important role in biogeochemical processes in freshwater environments. Therefore, the amount of DO in the water is very important to aquatic life in a lake (Kalff and Jacob, 2002). Too little oxygen can severely affect aquatic communities, often reducing diversity and population sizes. Low oxygen can directly kill or stress organisms such that they are not being able to successfully reproduce or grow. The total hardness content in water recorded higher value in winter season was due to leaching of materials rocks and 
dissolution in waters and similar results also reported by Naser, (2006). Hardness may be caused by natural accumulation of salts from soils, rocks and also from industrial wastes. The degree of hardness becomes greater as the calcium and magnesium content increases and is related to the concentration of multivalent cations dissolved in the water

Alkalinity is a measure of buffering capacity of water and is caused by calcium carbonate and bicarbonate and also to some extends due to phosphates and organic matter. Therefore, alkalinity analysis helps to know buffering capacity of water to adjust pH (Naser, 2006). These values are higher than the permissible limits suggesting that the water body have high concentration of Calcium Carbonate which increases the alkalinity of the area. Highest total alkalinity value observed during winter season may be due to dissolution of carbon dioxide present in soil zone, forming carbonic acid, in turn facilitating reaction(s) between the weathered rock and acidic water, thereby incorporating more and more leached ions into the solution, giving rise to alkaline waters. Similar observations on total alkalinity during winter season were observed by Goel et al., (1980) and Naser, (2006). According to Nasir, (2010), where limestone and sedimentary rocks and carbonate-rich soils are predominant, waters will often have high alkalinity.

Chloride in surface and groundwater mainly comes from both natural and anthropogenic sources, such as dissolution of mineral salts, use of inorganic fertilizers, landfill leachates, septic tank effluents, animal feeds, industrial effluents, irrigation drainage, and seawater intrusion in coastal areas (Nasir, 2010). Variation of chloride concentration in different seasons in the study area may be due to variation in natural flow of water and dilution factors. The high levels of chloride concentrations in summer season indicate high degree of pollution of waters due to industrial effluent, agricultural runoff and domestic waste (Naser, 2006).

Nitrate is the end product of aerobic degradation of organic nitrogen and it occurs very commonly in polluted water (Naser, 2006). Presence of Nitrate in water body stimulates the growth of plankton and water weeds which provide food for fish (Knepp and Arkin, 1973). Ganapati, (1960) pointed out that the concentration of nitrate $(>150 \mu \mathrm{g} / \mathrm{L})$ is an indicative of eutrophication and as such Surajpur wetland falls in eutrophic category which may leads to higher nitrate concentration in summer 2012-13. According to Goldman and Home, (1983), the concentration and rate of supply of nitrates is intimately connected with the land use practices of the surrounding area (catchment) which may also one of the reasons for higher level of nitrate concentration in water body of Surajpur wetland. In summer and monsoon 2011-12, there was a decrease in nitrate concentration due to less flow in the water body and excess growth of aquatic weeds such Alligator weed Alternanthera feloxeroides and Water Hyacinth Eichhornea crassipes clearly indicating nutrient rich water.

Fluoride, derived from fluorite (the principal fluoride mineral in igneous rocks) and the mineral apatite and mica, is generally present in only low concentration in groundwater (Nasir, 2010). Fluoride concentration recorded presence of only $1 \mathrm{mg} / \mathrm{l}$ in all the samples throughout the study period which is unfit for drinking purposes but good for wildlife and the values lies under the permissible limits.

Phosphorous is generally recognized as one of the key nutrients in the productivity of freshwaters as it is essential element determining fertility of lakes (Shah, 2012). 
Organic phosphates are formed primarily by biological processes. They are contributed to sewage by body waste and food residues. Phosphorus is essential in metabolism and the values are under permissible limits (Nasir, 2010).

Iron contaminated water above $1 \mathrm{ppm}$ can cause constipation accompanied by other physiological disorders but up to 3ppm it has no any affect to wildlife and biodiversity in water bodies (Maria, 2003). Winter season (2011-12) recorded maximum iron content (3ppm), suggesting heavy metal pollution in water body for drinking purposes, but it is under tolerance limit for wildlife and biodiversity.

The result described above indicates that the essential mineral nutrients are widely distributed and are within the normal range of water at various studied locations in the study area. There has no any pollution; no any organic waste is coming to the site. Nutrient levels are high in wetland habitat as wetlands have rich biomes and support high levels of biodiversity. At the end, it is concluded that the water is good enough to support rich biodiversity to form a complete food web in the Surajpur wetland ecosystem.

This is the first scientific study in Surajpur wetland forms the basis of research for the long term planning and management of the area. The study showed that Surajpur wetland has immense potential to sustain the good biodiversity with favourable environmental parameters, which helps in improvement of biodiversity. The area holds immense potential to sustain threatened flora, fauna and other biodiversity, as during the study period we have also recorded, 257 species of flora, 6 species of mammals, 186 species of birds, 13 species of herpeto-fauna, 15 species of fishes and 52 species of butterflies in the study area (Ansari, 2016).
The study helps assist management decisions regarding conserving this unique location. The study serves as the baseline information to develop a comprehensive science based management plan. Create and commit to implementing a long-term (at least 10-year) conservation management plan for the existing restored on-site native habitats, water bodies, and their buffers and create a guaranteed funding source for management. Collection of important information about the area can be used to form policies and management decisions regarding conserving the area's flora and fauna. The area is also developing into a major attraction and may be the source of tourism funding in future is it is managed and conserved correctly. There seems to be a major reawakening of interest in the area.

\section{Acknowledgement}

I express my gratitude to Greater Noida Industrial Development Authority for financial support to this study. The support received during field work from the state forest officials namely Shri Irfan Rasool Wani, Shri Sunil Dubey, Shri Prabhakar Bura, Shri Ashok Kumar, Shri Latoor Singh, Shri Ram Avtar Singh (Uttar Pradesh Forest Department) is highly appreciated. I am obliged to Mr. R. Singh, Dr. S. Worah, Dr. P. Gautam, Dr. A. Nawab and Dr. A. Pant (WWF-India) for their constant encouragement and support. The help rendered by our colleagues at Wildlife Institute of India (Dehradun) is also appreciated.

\section{References}

Ansari, N.A. 2016. A study on bird communities and its relationship with habitats structure in Surajpur wetland, Uttar Pradesh, India. Ph.D. Thesis, Kumaun University, Nainital, Uttarakhand, India. 
APHA. 2006. Standard Methods for the examination of Water and Wastewater. Edition 22 $2^{\text {nd }}$, American Public Health Association, Washington, DC.

Azmi, N., Anwar, M.R., Kumari, M. 2015. Water quality analysis of fish pond of Araria district, Bihar. Ind. J. Appl. Res., 5(1): 587-589.

BIS, (Bureau of Indian Standards) 1993. Specification for drinking water. Indian Standards (IS: 10500), New Delhi.

Chari, K.B. 2002. Application of GIS and Remote Sensing in the Environmental Assessment of two Wetlands of Peninsular India. Ph.D. Thesis, Pondicherry University, India.

Das, S.K., Saksena, D.N. 2001. Farm management and water quality in relation to growth of, Penaeus monodon in modified extensive shrimp culture system. J. Inland Fish. Soci. India, 33(2): 55-61.

Das, S.K., Sahoo, J.K., Saksena, D.N. 2001(a). Dynamics of abiotic factors in relation to growth of tiger shrimp, Panaeus monodon in traditional shrimp culture system. $J$. Inland Fish. Soci. India. 33(1):1-7.

Das, S.K., Sahoo, J.K., Saksena, D.N. 2000. Dynamics of abiotic factors in relation to growth of tiger prown, Panaeus monodon in traditional prown culture system. $J$. Inland Fish. Soci. India. 32: 28-34.

Das, S.K., Sahoo, J.K., Saksena, D.N. 2001(b). Sediment characteristics and benthic biomass in relation to growth of Panaeus monodon Fabricius in low saline confined pond. Indian J. Fish. 48(1): 55-61.

Eshleman, K.N, Hemond, H.F. 1985. The role of soluble organics in acid-base status of surface waters at Bickford Watershed, Massachusetts. Water Resou. Res., 15031510p.

Ganapati, S.V. 1960. Ecology of tropical water. In: Proc. of Symposium on Algol. ICAR, New Delhi. 214-218 pp.

Garg, R.K., Rao, R.J., Uchchariya, D., Shukla, G., Saksena, D.N. 2010. Seasonal variations in water quality and major threats to Ramsagar reservoir, India. Afr.
J. Environ. Sci. Tech., 4(2): 061-076.

Goldman, C.R., Home, A.J. 1983. Limnology. Pub. Mc Graw Hill. Inc. Japan. 464 pp.

Golterman, C.H., Clyma, R.S., Ohnstad, M.A.M. 1978. Methods for Physical and Chemical Analysis of Fresh Waters. IBP Handbook no. 8. Blackwell Scientific Publication, Oxford. 213 pp.

Groombridge, B., Jenkins, M. 1998. Freshwater Biodiversity: A Preliminary Global Assessment. Cambridge, United Nations Environment Programme-World Conservation Monitoring Centre, World Conservation Press.

Hammer, Harper, D.A.T., Ryan, P.D. 2001. PAST: Paleontological Statistics software package for education and data analysis. Paleantologia Electronica 4(1): 9

Kalff, Jacob. 2002. Limnology: Inland Water Ecosystems. Upper Saddle River, N.J. Prentice Hall.

Kerekes, J., Beadchamp, S., Tordon, R., Templey, C., Pollock, J. 1986. Organic versus anthropogenic acidity in tributaries of the Kejimkujik Water shed in Western Nova Scotia. Water, Air, Soil Pollut., 31: 165-298.

Knepp, G.L., Arkin, G.F. 1973. Ammonia Toxicity levels and Nitrate Tolerance of Channel Catfish. The Progressive FishCulturist, 35(4): 221-224.

Manral, U., Khudsar, F.A. 2013. Assessment of Wetland Water Quality and Avian Aiversity of a Human-Modified Floodplain Wetland on River Yamuna. Not. Sci Biol., 5(1): 25-33.

Manral, U., Raha, A., Solanki, R., Hussain, S.A., Babu, M.M, Mohan, D., Veeraswami, G.G., Sivakumar, K. and Talukdar, G. 2013. Plant species of Okhla Bird Sanctuary: A wetland of Upper Gangetic Plains, India. Check List, 9(2): 263-274.

Maria, A. 2003. The Costs of Water Pollution in India. In: Conference on Market Development of Water and Waste Technologies through Environmental Economics, 30-31 October 2003, Delhi. $55 \mathrm{p}$. 
Mishra, A., Tripathi, B.D. 2007. Seasonal and Temporal variations in physico-chemical and bacteriological characteristic's of river Ganga in Varanasi. Curr. World Environ., 2(2): 149-154.

Mishra, R.R., Rath, B., Thatoi, H. 2008. Water Quality Assessment of Aquaculture Ponds Located in Bhitarkanika Mangrove Ecosystem, Orissa, India. Turk. J. Fish. Aquat. Sci., 8: 71-77.

Naser, J.G. 2006. Ecological studies on aquatic vegetation in Pune's Wetlands. $\mathrm{PhD}$. Thesis, Department of Environmental Science, University of Pune, Maharashtra, India.

Nasir, U.P. 2010. Water Quality Assessment and Isotope studies of Vembanad Wetland System. Ph.D. Thesis., University of Calicut, Orissa.

Priyanka, Krishnan, G., Sharma, L.M., Yadav, B.K., Ghosh, N.C. 2016. Analysis of Water Level Fluctuations and TDS Variations in the Groundwater at Mewat (Nuh) District, Haryana (India). Curr. World Environ., 11(2): 388-398.

Rai, S., Chopra, A.K., Pathak, C., Sharma, D.K., Sharma, R., Gupta, P.M. 2011. Comparative study of some physicochemical parameters of soil irrigated with sewage water and canal water of Dehradun city, India. Archives of Appl. Sci. Rese. Schol. Res. Lib., 3(2): 318-325.

Rajashree, G. 1996. Biochemical parameters in India estuaries and overview. Poll. Res. 15(2): 121-128.
Ramachandra, T.V., Rishiram, R., Karthick, B. 2006. Zooplankton as Bioindicators: Hydro-Biological investigations in selected Bangalore Lakes. Technical Report Centre for Ecological Sciences, Indian Institute of Science. Bangalore. $115 \mathrm{pp}$.

Ramadas, S.G., Naik, K.T.P., Puttaiah, E.T. 2005. Diurnal variation in some physicochemical characteristics of Tungabhadra river water near Mylara during the great Sri Mylaralingeshwara fair. Eco. Env. Cons., 11(3-4): 445-449.

Ramesh, M., Saravanan, M., Pradeepa, G. 2007. Studies on the physicochemical characteristics of the Singallunar Lake, Coimbatore, India. In: Proceeding of National Seminar on Limnology. Maharana Pratap University of Agriculture and Technology, Udaipur, India.

Sahu, B.K., Rao, R.J., Behera, S. 1995. Studies of some physicochemical characteristics of the Ganga river water (RishikeshKanpur) within twenty four hours during winter 1994. Ecol. Env. Cons., 1(1-4): 3538.

Shah, J.A. 2012. Crustacean Community of Wular Lake, Kashmir. M.Phil. Thesis. Centre of Research for Development (Cord), University of Kashmir. 208 pp.

Spjotvoll, E., Stoline, M.R. 1973. An extension of the T-method of multiple comparisons to include the cases with unequal sample sizes. J. American Stat. Asso., 68: 97678.

\section{How to cite this article:}

Nasim Ahmad Ansari. 2017. Seasonal variations in physicochemical parameters of Surajpur wetland, National Capital Region, India. Int.J.Curr.Microbiol.App.Sci. 6(2): 971-987.

doi: http://dx.doi.org/10.20546/ijcmas.2017.602.110 